\title{
LEAD AND ZINC IN THE STRUCTURE OF ORGANIC AND MINERAL SOIL COMPONENTS ${ }^{(1)}$
}

\author{
Larissa Kummer ${ }^{(2)}$, Vander de Freitas Melo ${ }^{(3)} \&$ Yara Jurema Barros ${ }^{(4)}$
}

\begin{abstract}
SUMMARY
In addition to the more reactive forms, metals can occur in the structure of minerals, and the sum of all these forms defines their total contents in different soil fractions. The isomorphic substitution of heavy metals for example alters the dimensions of the unit cell and mineral size. This study proposed a method of chemical fractionation of heavy metals, using more powerful extraction methods, to remove the organic and different mineral phases completely. Soil samples were taken from eight soil profiles $(0-10,10-20$ and $20-40 \mathrm{~cm})$ in a $\mathrm{Pb}$ mining and metallurgy area in Adrianópolis, Paraná, Brazil. The $\mathbf{P b}$ and $\mathrm{Zn}$ concentrations were determined in the following fractions (complete phase removal in each sequential extraction): exchangeable; carbonates; organic matter; amorphous and crystalline Fe oxides; $\mathrm{Al}$ oxide, amorphous aluminosilicates and kaolinite; and residual fractions. The complete removal of organic matter and mineral phases in sequential extractions resulted in low participation of residual forms of $\mathrm{Pb}$ and $\mathrm{Zn}$ in the total concentrations of these metals in the soils: there was lower association of metals with primary and 2:1 minerals and refractory oxides. The powerful methods used here allow an identification of the complete metal-mineral associations, such as the occurrence of $\mathrm{Pb}$ and $\mathrm{Zn}$ in the structure of the minerals. The higher incidence of $\mathrm{Zn}$ than $\mathrm{Pb}$ in the structure of $\mathrm{Fe}$ oxides, due to isomorphic substitution, was attributed to a smaller difference between the ionic radius of $\mathrm{Zn}^{2+}$ and $\mathrm{Fe}^{3+}$.

Index terms: isomorphic substitution, sequential analysis, iron oxide, kaolinite.
\end{abstract}

(1) Received for publication on November 2, 2012 and approved on February 28, 2013.

(2) Professor, Department of Chemistry and Biology, UTFPR. Rua Deputado Heitor de Alencar Furtado, 4900. CEP 81280-340 Curitiba (PR). E-mail: lkummer@utfpr.edu.br

(3) Professor, Department of Soils and Agricultural Engineering, UFPR. Rua dos Funcionários, 1540, Cabral. CEP 80035-050 Curitiba (PR). E-mail: vanderfm@ufpr.br

(4) Master in Soil Science, UFPR. E-mail: yarajuba@gmail.com 


\title{
RESUMO: CHUMBO E ZINCO NA ESTRUTURA DE COMPONENTES ORGÂNICOS E MINERAIS DE SOLOS
}

\begin{abstract}
Além das formas mais reativas, os metais podem ocorrer na estrutura de minerais e a soma de todas essas formas define os seus teores totais, em diferentes frações de solo. A substituição isomórfica por metais pesados altera, por exemplo, as dimensões da célula unitária e o tamanho de minerais. Este estudo teve como objetivo propor um método de fracionamento químico de metais pesados, usando métodos de extração mais fortes, para remover completamente a matéria orgânica e as diferentes fases minerais do solo. As amostras de solo (0-10, 10-20 e 20-40 cm) foram coletadas de oito perfis de solo, em uma área de mineração $e$ processamento de $\mathrm{Pb}$ em Adrianópolis, PR, Brasil. As concentrações de $\mathrm{Pb}$ e Zn foram determinadas nas seguintes frações (remoção total em cada fase de extração sequencial): trocável; carbonatos; matéria orgânica; óxidos de Fe amorfos e cristalinos; óxido de Al, aluminossilicatos amorfos e caulinita; e residual. A remoção completa da matéria orgânica e das fases minerais nas extrações sequenciais resultou em baixa participação da forma residual de Pb e Zn, nas concentrações totais desses metais nos solos. Houve menor associação dos metais aos minerais primários, minerais 2:1 e óxidos refratários. Os métodos com maior poder de extração permitiram identificar a associação completa entre metal-mineral, como a ocorrência de Pbe $Z n$ no interior da estrutura dos minerais. A maior incidência de Zn, quando comparados com $\mathrm{Pb}$, na estrutura dos óxidos de Fe, por substituição isomorfa, foi atribuída a uma menor diferença entre o raio iônico do $\mathrm{Zn}^{2+}$ e $\mathrm{Fe}^{3+}$.
\end{abstract}

Termos de Indexação: substituição isomórfica, análise sequencial, óxidos de ferro, caulinita.

\section{INTRODUCTION}

Metals preserved in soils in different forms can be separated by fractionation techniques that allow inferences on the element concentration (reactive or total forms) in several organic and mineral fractions. The results of sequential extraction, operationally defined as chemical fractionation, depend on the characteristics of the extraction process, such as: type, concentration and $\mathrm{pH}$ of reagents; sample/extractor ratio; time and temperature of extraction; stirring methods and definition of metal forms; among others (Shiowatana et al., 2001).

There are several metal speciation methods for environmental purposes and the most commonly used were proposed by Tessier et al. (1979), Shuman (1979), Sposito et al. (1982), Miller et al. (1986), and Mann \& Ritchie (1993). The extraction of mineral and organic constituents is only partially due to the nature of the treatments and the fractions normally considered are: exchangeable; carbonates; $\mathrm{Fe}, \mathrm{Al}$ and $\mathrm{Mn}$ oxides and hydroxides; organic matter and residual fractions. These methods are applied to studies of environmental diagnostic since the extraction of heavy metals at each step is limited to more reactive forms.

However, there is no method of sequential extractions of heavy metals for basic studies to determine the composition of the soil constituents, by the total extraction of mineral and organic constituents indicating the actual contribution of each phase to the total heavy metal contents. This total extraction can also provide information about the conditions of formation of the soil constituents and the level of isomorphic substitution of metals in the mineral structure. For example, to determine the reactive heavy metal fraction associated with $\mathrm{Fe}$ oxides diluted solutions of ammonium oxalate are commonly used. This extractor is only efficient in solubilizing low crystalline Fe oxides (e.g. ferrihydrite) (Norrish \& Taylor, 1961). It is also noteworthy that the solution can extract heavy metals specifically adsorbed on the surface of crystalline $\mathrm{Fe}$ oxides, but not the ones in the structure as a result of $\mathrm{Fe}^{3+}$ isomorphic substitution. For a complete extraction of crystalline Fe oxides (hematite and goethite), strong reducing agents, such as sodium DCB (dithionite-citratebicarbonate) are used (Mehra \& Jackson, 1960). Therefore, the loss of sample mass during the sequential extractions by traditional methods for environmental purposes does not represent a total extraction of constituents at each step and the less reactive metal forms are computed in the residual phase.

Melo et al. (2002, 2003) proposed a method of sequential extractions of total removal of each mineral phase (more aggressive extractions) for the speciation of total $\mathrm{K}$ in the clay fraction of Oxisols from different regions of Brazil. As the solubilization of clay minerals was total (verified by X-ray diffraction) the authors found that about $50 \%$ of total $\mathrm{K}$ was contained in the structure of 1:1 minerals (interstratifications with mica layers) and the other half in residues of micaceous minerals that resisted chemical weathering. In this study, there was no concern about $\mathrm{K}$ availability to plants, but to identify the sources of structural $\mathrm{K}$ forms in highly weathered soils.

The occurrence of structural forms of heavy metals in soils is mainly attributed to isomorphic substitution 
in primary and secondary minerals. Several authors have used methods of physical analysis (X-ray diffraction, scanning electron microscopy equipped with energy-dispersive X-ray spectroscopy and thermal analysis) to study the structural forms of heavy metals in minerals (Castaldi et al., 2008; Lu et al., 2009; Valente et al., 2010). In studies on pollution in the coastal Mediterranean Sea of Spain, Auernheimer \& Chinchon (1997) concluded that heavy metals displace $\mathrm{Ca}$ of aragonite or calcite in crystalline structures by isomorphic substitution. Perin et al. (1997) evaluated the sediment pollution of Bahia da Guanabara, Rio de Janeiro, Brazil, and observed a more pronounced isomorphic substitution by $\mathrm{Cu}$ and $\mathrm{Cd}$ in Mn hydrous oxides than in amorphous Fe oxides. With respect to magnetic oxides (magnetite and maghemite), $\mathrm{Fe}$ is mostly replaced by $\mathrm{Al}^{3+}, \mathrm{Ti}^{4+}, \mathrm{Mg}^{2+}$, $\mathrm{Zn}^{2+}$, and $\mathrm{Mn}^{2+}$ (Schwertmann \& Fechter, 1984) and in the synthesized maghemites, Batista el al. (2008) reported high degrees of isomorphic substitution of $\mathrm{Fe}^{3+}$ for $\mathrm{Zn}^{2+}$ (maximum of $0.34 \mathrm{~mol} \mathrm{~mol}^{-1}$ ). According to Luckham \& Rossi (1999), the isomorphic substitution of $\mathrm{Al}^{3+}$ for $\mathrm{Zn}^{2+}$ in the octahedral layers results in the formation of a net negative charge on the surface of the philosilicate minerals. Liang et al. (2010) also considered the possibility of isomorphic substitution of $\mathrm{Mg}^{2+}$ for $\mathrm{Pb}^{2+}$ in the trioctahedral brucite sheet.

Kummer et al. (2011) subjected the same samples as used in this study (from different locations in a heavy metal mining and metallurgy area, Adrianópolis - PR, Brazil) to seven steps of conventional sequential extraction (Mann \& Ritchie, 1993) for the speciation of the total $\mathrm{Pb}$ and $\mathrm{Zn}$ levels in the more reactive forms of greater environmental interest. Therefore, the potential for contamination of soil, plant, water, sediments and organisms was extensively discussed by Kummer et al. (2011) and in other studies developed in the same area, focused on environmental aspects (Andrade et al., 2009a,b; Barros et al. 2010a,b; Buschele et al., 2010; Kummer et al., 2010; Melo et al., 2012).

Thus, this study evaluated the total amount of occluded and structural forms of $\mathrm{Pb}$ and $\mathrm{Zn}$ in the organic matter and in different mineral phases to determine the real distribution of the total amounts of these metals in the soil constituents and relate this distribution with the level of isomorphic substitution and the mineral formation conditions. For this purpose, a chemical fractionation method of $\mathrm{Pb}$ and $\mathrm{Zn}$ was proposed, based on powerful extraction methods of soil constituents. This method was used to study the mineral composition and should not be considered as an alternative to the many sequential procedures described in the literature that determine more reactive forms of heavy metal, since the more stable forms of these elements are not directly related to environmental pollution.

\section{MATERIALS AND METHODS}

\section{Studied area and soil sampling}

The study was carried out in Adrianópolis, Metropolitan Region of Curitiba, Paraná, Brazil, in eight soil profiles from different locations in an area of $\mathrm{Pb}$ mining and metallurgy (Figure 1). The criteria to select the sites for soil sampling were presented by Andrade et al. (2009a) and their characteristics are shown in table 1.

Soil samples were collected at 0-10, 10-20 and 20$40 \mathrm{~cm}$ depth, air-dried and passed through a $2 \mathrm{~mm}$ mesh sieve. The soil texture and chemical characteristics (methods described in Embrapa, 1997) and clay mineralogy (methods presented by Melo et al., 2001, 2002) of samples are presented in table 2 .

\section{Total $\mathbf{P b}$ and $\mathrm{Zn}$ concentrations of the soils}

Digestion of soil samples was carried out in a microwave oven (Milestone Ethos Plus) by mixing 0.25 $\mathrm{g}$ of soil, previously dried at $40^{\circ} \mathrm{C}$ for $24 \mathrm{~h}, 4 \mathrm{~mL}$ of concentrated $\mathrm{HNO}_{3}, 3 \mathrm{~mL}$ of concentrated $\mathrm{HF}$ and 1 $\mathrm{mL}$ of $\mathrm{H}_{2} \mathrm{O}_{2}(30 \% \mathrm{v} / \mathrm{v})(U S E P A, 1996)$. The flasks were heated for $10 \mathrm{~min}$ at $1000 \mathrm{~W}$ to $200 \pm 2{ }^{\circ} \mathrm{C}$ and

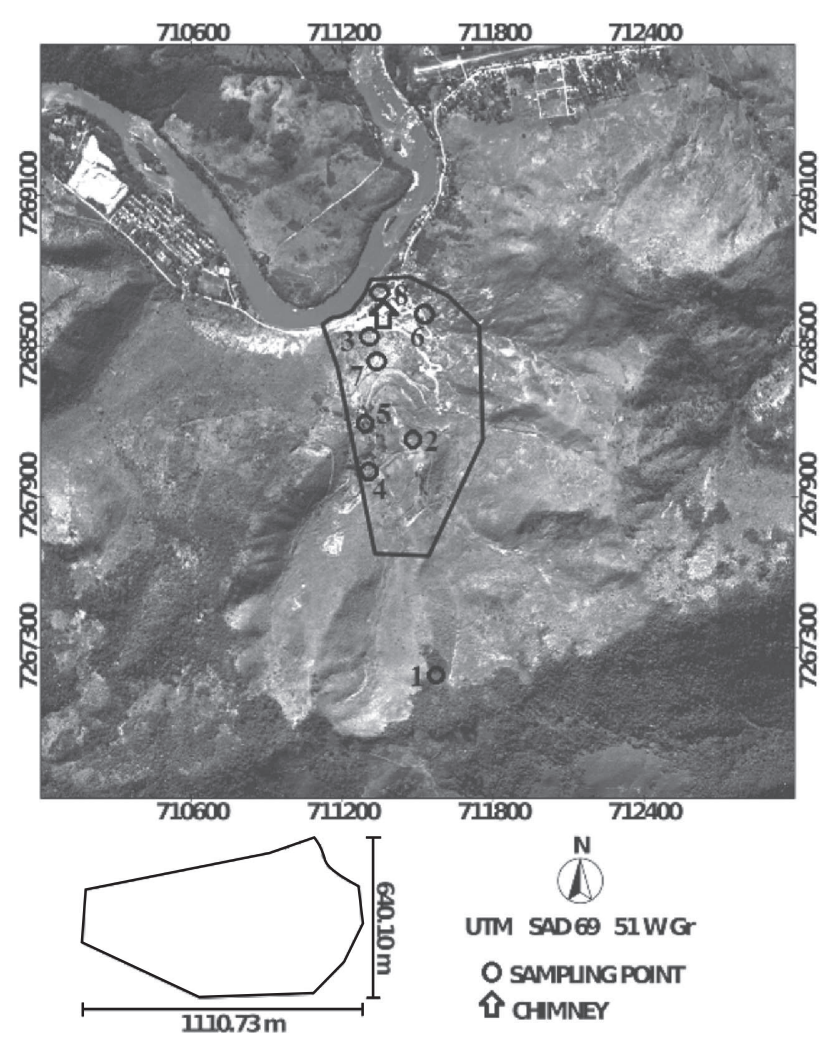

Figure 1. Georeferenced aerial photo of the study area under direct influence of $\mathrm{Pb}$ mining and metallurgy (the abandoned factory is located close to the Ribeira river), in Adrianópolis (PR), Brazil. The most contaminated central area (49.8 ha) is marked by the contour line. 
Table 1. Location, classification and characteristics of the soil sampling sites in Adrianópolis, Brazil

\begin{tabular}{|c|c|c|c|c|c|c|}
\hline \multirow[b]{2}{*}{ Soil } & \multicolumn{2}{|c|}{ UTM (22J) } & \multirow{2}{*}{$\begin{array}{c}\text { Altitude } \\
\text { /distance } \\
\text { /1) }\end{array}$} & \multirow{2}{*}{$\begin{array}{c}\text { Brazilian } \\
\text { classification }\end{array}$} & \multirow{2}{*}{$\begin{array}{l}\text { U.S. } \\
\text { taxonomy }^{(3)}\end{array}$} & \multirow[b]{2}{*}{ Observation } \\
\hline & $\begin{array}{l}\text { N-S } \\
\text { Latitude }\end{array}$ & $\begin{array}{c}\text { E-W } \\
\text { Longitude }\end{array}$ & & & & \\
\hline 1 & $7267313 \mathrm{~S}$ & $711502 \mathrm{~W}$ & $546 / 1,560$ & Lithic Neosol & Ustorthent & $\begin{array}{l}\text { Reference soil under native } \\
\text { forest at highest elevation. } \\
\text { Parent material: carbonate } \\
\text { rocks/granitic complex. }\end{array}$ \\
\hline 2 & 7268164 & 711513 & $326 / 563$ & Haplic Cambisol & Ustrochept & $\begin{array}{l}\text { Intermediate elevation area. } \\
\text { Vegetation cover of dallis grass } \\
\text { (Paspalum notatum). Parent } \\
\text { material: carbonate rocks/ } \\
\text { granitic complex. }\end{array}$ \\
\hline 3 & 7268555 & 711287 & $165 / 45$ & Lithic Neosol & Ustorthent & $\begin{array}{l}\text { Close to the factory. Vegetation } \\
\text { cover with legume trees } \\
\text { (Leucaena sp.). Parent material: } \\
\text { carbonate rocks/granitic complex. }\end{array}$ \\
\hline 4 & 7267907 & 711187 & $327 / 590$ & $\begin{array}{l}\text { Mixture of sediment } \\
+ \text { fine waste }\end{array}$ & - & $\begin{array}{l}\text { A valley filled with metallurgical } \\
\text { wastes. }\end{array}$ \\
\hline 5 & 7268070 & 711360 & $316 / 455$ & $\begin{array}{l}\text { Mixture of soil } \\
+ \text { coarse waste }^{(2)}\end{array}$ & - & $\begin{array}{l}\text { Greater occurrence of } \\
\text { metallurgical waste on the } \\
\text { surface, partly incorporated in } \\
\text { soil profile. }\end{array}$ \\
\hline 6 & 7268671 & 711572 & $202 / 295$ & $\begin{array}{l}\text { Quartzarenic } \\
\text { Neosol }\end{array}$ & $\begin{array}{l}\text { Quartzi- } \\
\text { psamment }\end{array}$ & $\begin{array}{l}\text { Factory surroundings. Vegetation } \\
\text { cover of secondary forest and } \\
\text { fern (Pteridium aquilinum). } \\
\text { Parent material: quartzite. }\end{array}$ \\
\hline 7 & 7268499 & 711158 & $194 / 321$ & Haplic Inceptsol & Haplustept & $\begin{array}{l}\text { Same characteristics as of soil } 3 \text {, } \\
\text { but farther away from the } \\
\text { factory. }\end{array}$ \\
\hline 8 & 7268701 & 711331 & $157 / 64$ & Fluvic Neosol & Ustfluvent & $\begin{array}{l}\text { Close to the Ribeira river at the } \\
\text { lowest elevation. Little vegetation } \\
\text { cover (some Poaceae plants). } \\
\text { Parent material: fluvial sand } \\
\text { deposits, sediments. }\end{array}$ \\
\hline
\end{tabular}

${ }^{(1)}$ Straight-line distance from the sampling point to the factory. ${ }^{(2)}$ Due to lack of pedogenic horizons, it was not possible to classify the soil profile. ${ }^{(3)}$ Approximate correlation with U.S Soil Taxonomy.

maintained for $20 \mathrm{~min}$. The suspension was filtered to separate possible residual refractory material (e.g. titanium oxides) and $\mathrm{Pb}$ and $\mathrm{Zn}$ concentrations were determined by optical emission spectrometry with inductively coupled plasma (ICP-OES). Boric acid was added to remove the HF excess from the extracts to avoid damaging the quartz tube of the ICP-OES (USEPA, 1996).

\section{Chemical fractionation of $\mathrm{Pb}$ and $\mathrm{Zn}$ of the soils}

The sequential extraction of $\mathrm{Pb}$ and $\mathrm{Zn}$ in soil samples was based on a method proposed by Melo et al. (2002, 2003), developed to estimate the contribution of different clay minerals (structural forms) in the total $\mathrm{K}$ content in this fraction. $\mathrm{Pb}$ and $\mathrm{Zn}$ were analyzed in the following forms (total extraction at each step): exchangeable; carbonate; organic matter; amorphous and crystalline $\mathrm{Fe}$ oxides; $\mathrm{Al}$ oxides, low crystalline aluminosilicates and kaolinte; residual fractions.

In comparison to the traditional methods of sequential extractions to estimate only the most reactive forms of heavy metals in several soil constituents (Tessier et al., 1979; Shuman, 1979; Sposito et al., 1982; Miller et al., 1986; Mann \& 
Table 2. Chemical and textural analysis of soil samples and mineralogical analyses of clay fraction(1)

\begin{tabular}{|c|c|c|c|c|c|c|c|c|c|c|c|}
\hline \multirow[b]{2}{*}{ Profile } & \multirow[b]{2}{*}{ Depth } & \multirow[b]{2}{*}{$\underset{\left(\mathbf{H}_{2} \mathbf{O}\right)}{\mathbf{p H}}$} & \multirow[b]{2}{*}{$\mathrm{CEC}_{\mathrm{pH} \mathrm{7,0}}$} & \multirow[b]{2}{*}{ OC } & \multirow[b]{2}{*}{ Sand } & \multirow[b]{2}{*}{ Clay } & \multicolumn{5}{|c|}{ Clay fraction } \\
\hline & & & & & & & $\mathbf{K a}$ & Gb & Hm & Gt & $\begin{array}{c}\text { Amorphous } \\
\text { material }\end{array}$ \\
\hline & $\mathrm{cm}$ & & $\mathrm{cmol}_{\mathrm{c}} \mathrm{dm}^{-3}$ & $\mathrm{~g} \mathrm{dm}^{-3}$ & & & & - $\mathrm{g} \mathrm{l}$ & & & \\
\hline \multirow[t]{3}{*}{1} & $0-10$ & 6.7 & 31.7 & 45.0 & 162 & 477 & 537.4 & 35.9 & 19.7 & 7.8 & 55.6 \\
\hline & $10-20$ & 6.4 & 29.3 & 29.3 & 169 & 507 & 541.6 & 34.4 & 33.1 & 7.7 & 75.3 \\
\hline & $20-40$ & 6.8 & 31.2 & 26.9 & 170 & 516 & 534.2 & 33.4 & 19.0 & 4.1 & 50.0 \\
\hline \multirow[t]{3}{*}{2} & $0-10$ & 6.6 & 34.7 & 37.7 & 98 & 441 & 438.6 & 51.3 & 9.7 & 21.4 & 57.8 \\
\hline & $10-20$ & 7.3 & 34.4 & 28.1 & 106 & 453 & 423.3 & 50.0 & 19.4 & 30.4 & 54.6 \\
\hline & $20-40$ & 7.7 & 30.5 & 19.0 & 89 & 440 & 441.6 & 40.0 & 10.6 & 31.8 & 44.6 \\
\hline \multirow[t]{3}{*}{3} & $0-10$ & 6.9 & 29.2 & 45.6 & 204 & 434 & 534.4 & 43.0 & 14.1 & 11.8 & 54.1 \\
\hline & $10-20$ & 6.8 & 29.1 & 37.7 & 204 & 464 & 535.5 & 36.2 & 23.0 & 17.1 & 42.6 \\
\hline & $20-40$ & 6.8 & 28.9 & 37.7 & 188 & 424 & 518.5 & 41.2 & 21.5 & 18.4 & 26.4 \\
\hline \multirow[t]{3}{*}{4} & $0-10$ & 8.4 & 25.5 & 26.3 & 179 & 266 & 494.8 & 39.5 & 0.0 & 36.8 & 60.6 \\
\hline & $10-20$ & 8.3 & 35.5 & 6.3 & 120 & 212 & 441.3 & 29.3 & 0.1 & 27.6 & 86.2 \\
\hline & $20-40$ & 8.4 & 31.3 & 6.3 & 99 & 255 & 497.8 & 39.9 & 3.1 & 41.8 & 34.7 \\
\hline \multirow[t]{3}{*}{5} & $0-10$ & 8.3 & 11.3 & 28.1 & 807 & 48 & 443.4 & 35.1 & 3.2 & 37.9 & 96.9 \\
\hline & $10-20$ & 8.3 & 26.4 & 20.8 & 336 & 349 & 532.4 & 45.4 & 0.8 & 41.4 & 26.0 \\
\hline & $20-40$ & 8.0 & 30.5 & 13.0 & 184 & 313 & 445.0 & 46.1 & 4.8 & 27.3 & 19.9 \\
\hline \multirow[t]{3}{*}{6} & $0-10$ & 4.9 & 7.5 & 11.8 & 730 & 124 & 525.6 & 21.2 & 0.0 & 41.1 & 58.4 \\
\hline & $10-20$ & 4.6 & 4.3 & 6.9 & 747 & 95 & 505.8 & 16.2 & 0.0 & 27.4 & 102.4 \\
\hline & $20-40$ & 4.6 & 3.5 & 6.3 & 777 & 64 & 494.0 & 24.4 & 0.0 & 41.2 & 75.2 \\
\hline \multirow[t]{3}{*}{7} & $0-10$ & 8.3 & 27.1 & 30.5 & 151 & 483 & 595.2 & 34.8 & 19.2 & 22.2 & 69.4 \\
\hline & $10-20$ & 8.3 & 29.5 & 18.4 & 125 & 515 & 601.8 & 32.7 & 13.6 & 28.6 & 61.7 \\
\hline & $20-40$ & 8.2 & 30.7 & 18.4 & 117 & 549 & 674.5 & 45.5 & 10.5 & 26.9 & 61.1 \\
\hline \multirow[t]{3}{*}{8} & $0-10$ & 8.3 & 13.3 & 20.8 & 586 & 149 & 501.8 & 32.2 & 0.0 & 38.5 & 71.9 \\
\hline & $10-20$ & 8.3 & 14.0 & 20.8 & 553 & 206 & 509.1 & 40.2 & 0.0 & 45.4 & 91.1 \\
\hline & $20-40$ & 8.2 & 21.9 & 17.8 & 353 & 318 & 538.3 & 21.5 & 7.6 & 35.1 & 79.8 \\
\hline
\end{tabular}

(1) OC: organic carbon, Ka: kaolinite, Gb: gibbsite, $\mathrm{Hm}$ : hematite, Gt: goethite, amorphous material: extraction with 0.2 mol $\mathrm{L}^{-1}$ ammonium oxalate. Modified from Kummer et al. (2010).

Ritchie, 1993), stronger extractions were used in this study to estimate the total concentrations of these elements associated with different soil components. The main adaptations of the traditional methods were: use of more reactive extractors at higher concentration; increase in soil/solution ratio; longer contact period between soil/solution.

After each extraction, $\mathrm{Pb}$ and $\mathrm{Zn}$ concentrations were determined by ICP-OES. Other common procedures for all extractions were: a) to measurement of initial dry weight (before extraction) and final weight (after extraction), the samples was ovendrying at $40^{\circ} \mathrm{C}$ for $24 \mathrm{~h}$; b) washing of the residue of each extraction with $0.5 \mathrm{~mol} \mathrm{~L}^{-1}\left(\mathrm{NH}_{4}\right)_{2} \mathrm{CO}_{3}$ and deionized water to remove salt excess; $\mathrm{c}$ ) centrifugation of the suspension at 3,500 rpm for 10 min during extractions and sample washing.

Step 1 - Exchangeable fraction (non-specific $\mathrm{Zn}$ and $\mathrm{Pb}$ adsorption): $3 \mathrm{~g}$ soil and $30 \mathrm{~mL} 0.5 \mathrm{~mol} \mathrm{~L}^{-1}$ $\mathrm{Ca}\left(\mathrm{NO}_{3}\right)_{2}$ were stirred for $1 \mathrm{~h}$ in a centrifuge tube.
Step 2 - Carbonate fraction: $30 \mathrm{~mL}$ of $1.0 \mathrm{~mol} \mathrm{~L}^{-1}$ sodium acetate at $\mathrm{pH} 5.0$ (adjusted with acetic acid) were added to the tube (residue from step 1 ) and stirred for $5 \mathrm{~h}$. The material was centrifuged and the supernatant was filled into a bottle. This procedure was repeated twice, and the extracts were collected in the same flask.

Step 3 - Amorphous and crystalline Fe oxide fraction: The residue from step 2 was treated with $40 \mathrm{~mL} 0.3$ mol L-1 sodium citrate, $5 \mathrm{~mL} 1 \mathrm{~mol} \mathrm{~L}^{-1}$ sodium bicarbonate and $1 \mathrm{~g}$ sodium dithionite citrate bicarbonate (DCB) for $30 \mathrm{~min}$ at $70^{\circ} \mathrm{C}$, with occasional shaking (Mehra \& Jackson, 1960). After the first 15 min, a new portion with $1 \mathrm{~g}$ of dithionite was added. This procedure was repeated twice and the extracts were combined.

Step 4 - Al Oxides, low crystalline aluminosilicates and kaolinite fraction: $1.0 \mathrm{~g}$ of the previous residue of step 3 was transferred to teflon flasks and $100 \mathrm{~mL}$ $5.0 \mathrm{~mol} \mathrm{~L}^{-1} \mathrm{NaOH}$ were added. This material was 
maintained in a sand bath at $220^{\circ} \mathrm{C}$ for $1.5 \mathrm{~h}$ and then transferred to a tube, centrifuged and the supernatant placed in a $100 \mathrm{~mL}$ volumetric flask. To remove the resulting sodalite $\left[\mathrm{Na}_{4} \mathrm{Al}_{3} \mathrm{Si}_{3} \mathrm{O}_{12}(\mathrm{OH})\right]$, the residue was washed twice with $90 \mathrm{~mL}$ of $0.5 \mathrm{~mol} \mathrm{~L}^{-1}$ $\mathrm{HCl}$ (Norrish \& Taylor, 1961), with a contact time of 10 min per extraction (Singh \& Gilkes, 1991). The $\mathrm{Pb}$ and $\mathrm{Zn}$ contents of this phase were obtained by the sum of solutions $(\mathrm{NaOH}+\mathrm{HCl})$.

Step 5 - Residual fraction: digestion in a microwave oven, mixing $0.25 \mathrm{~g}$ of residue (step 4 ) with $4 \mathrm{~mL}$ of concentrated $\mathrm{HNO}_{3}, 3 \mathrm{~mL}$ of concentrated $\mathrm{HF}$ and 1 $\mathrm{mL} \mathrm{H}_{2} \mathrm{O}_{2}(30 \% \mathrm{v} / \mathrm{v})$. The same procedures of total extraction were applied, as previously described.

The percentage contribution of $\mathrm{Pb}$ and $\mathrm{Zn}$ extracted from different sequential treatments in its total contents were calculated, considering the amount of material removed and the concentrations of those metals obtained in each sequential extraction. The data of Kummer et al. (2011), who subjected the same soil samples to seven steps of sequential extraction of reactive forms of heavy metals, were used to compare the performance of the extraction methods proposed here.

To monitor the effect of extractions on the mineralogy, the residue of each step was dried and sieved through a $0.2 \mathrm{~mm}$ mesh (powder sample) for $\mathrm{X}$-ray diffraction analysis (XRD). The diffractograms were obtained in a vertical goniometer, at speed of $1^{\circ} 2 \theta \mathrm{min}^{-1}$ and range from 2 to $65^{\circ} 2 \theta$. The XRD, equipped with $\mathrm{Ni}$ filter and using $\mathrm{CuKa}$ radiation, was carried out at $20 \mathrm{kV}$ and $40 \mathrm{~mA}$.

\section{RESULTS AND DISCUSSION}

Andrade et al. (2009a,b), Barros et al. (2010a,b), Buschele et al. (2010), Kummer et al. (2010, 2011) and Melo et al. (2012) discussed in detail the relationship between total $\mathrm{Pb}$ and $\mathrm{Zn}$ soil contents (Tables 3 and 4) with the sampling locations (Table 1) and the level of diffusion of these contaminants in soils, water, sediments, organisms, and plants in the study area.

Considering the $\mathrm{Pb}$ contents (Table 3 ) and soil mass loss in each phase of sequential extraction (Table 5), between 96 and $102 \%$ of the total $\mathrm{Pb}$ had been recovered at the end of the six steps (normalized data in Figure 2). After five steps, prior to the extraction of the residual fractions, the total sample mass loss ranged from 8.8 to $63.7 \%$ (Table 5). Thus, the $\mathrm{Pb}$ concentrations in the sequential analysis (Table 3 ) refer to effective concentrations at each step. For example, to calculate the $\mathrm{Pb}$ concentrations in the amorphous and crystalline Fe oxide phase, the final sample mass (residue) of the previous extraction (organic matter) was considered. By the traditional methods of sequential extractions, the heavy metal contents in all steps are only calculated in relation to the initial sample mass of the first treatment (exchangeable phase). Therefore, for the same sample, the simple sum of $\mathrm{Pb}$ contents in sequential extractions would not approach the total $\mathrm{Pb}$ levels ("Total" in table 3). This control of sample soil mass at each sequential extraction is even more important when more aggressive reagents (total extraction of each phase) are used, as in this study.

Since in most samples and steps of the sequential analysis, $\mathrm{Zn}$ concentrations were below the detection limits of ICP-AES and total concentrations were also low (Table 4), the percentage contribution of the different metal forms in relation to their total contents was not estimated.

The high $\mathrm{pH}$ values of soils (Table 2), influenced by limestone rocks in the area (Table 1), increased the forms of $\mathrm{Pb}$ and $\mathrm{Zn}$ associated with carbonates (Tables 3 and 4 ). At $\mathrm{pH}$ over $6.36, \mathrm{HCO}_{3}$ ions predominate in the soil, which can promote the precipitation of metal in the form of $\mathrm{Pb}\left(\mathrm{HCO}_{3}\right)_{2}$ (Lindsay, 2001). Another possibility is the occurrence of structural forms of these metals in carbonate minerals (calcite and aragonite) by isomorphic substitution of $\mathrm{Ca}^{2+}$ by $\mathrm{Pb}^{2+}$ and $\mathrm{Zn}^{2+}$ (Auernheimer $\&$ Chinchon, 1997). Both calcite and aragonite were identified in the soils by X-ray diffraction (Figure 3 ). Due to high concentrations of $\mathrm{Pb}$ carbonate (Table 3), the participation of these forms in total metal content was also significant (Figure 2). Kummer et al. (2011) used the sequential analysis in the same soil samples for speciation of the total $\mathrm{Pb}$ and $\mathrm{Zn}$ concentrations in their more reactive forms (partial extraction of mineral and organic phases - Mann \& Ritchie, 1993) and obtained an average concentration (24 samples) of $\mathrm{Pb}$ associated to carbonates (single extraction with $0.1 \mathrm{~mol} \mathrm{~L}^{-1} \mathrm{pH} 5 \mathrm{Na}$ acetate) of $1,921.6 \mathrm{mg} \mathrm{kg}^{-1}$. Raising the concentration of $\mathrm{Na}$ acetate and the number of extractions increased the average of $\mathrm{Pb}$ concentration for the same fraction to $4,362.9 \mathrm{mg} \mathrm{kg}^{-1}$.

During the step of total extraction of organic matter, there was practically no release of $\mathrm{Pb}$ and $\mathrm{Zn}$ (Tables 3 and 4), even though other studies showed a strong interaction between organic colloid and heavy metal (Kabata Pendias \& Pendias, 2001; Zhang et al., 2005). The selectivity of the extractor used in the previous step, responsible for extraction of carbonateassociated metals (sodium acetate), may have been low resulting in the simultaneous extraction of metals bonded to organic matter and amorphous and crystalline Fe oxides. These effects were associated to acetic acid, used to adjust the solution of sodium acetate at pH 5.0 (Stover et al., 1976). Another possibility of underestimating the levels of $\mathrm{Pb}$ and $\mathrm{Zn}$ in the organic matter is the reprecipitation and redistribution of metals during the extraction processes with sodium hypochlorite under alkaline conditions (Miller et al., 1986; Tu et al., 1994; Raksasataya et al., 1996). 
Table 3. Total $\mathrm{Pb}$ contents and $\mathrm{Pb}$ in different forms obtained by sequential extractions from soil samples ${ }^{(1)}$

\begin{tabular}{|c|c|c|c|c|c|c|c|c|}
\hline Profile & Depth & Total & $\mathrm{Ca}\left(\mathrm{NO}_{3}\right)_{2}$ & $\mathrm{CH}_{3} \mathrm{COONa}$ & $\mathrm{NaClO}$ & DCB & $\mathrm{NaOH}$ & $\mathrm{HF} / \mathrm{HNO}_{3} / \mathrm{H}_{2} \mathrm{O}_{2}$ \\
\hline & $\mathrm{cm}$ & & & & $\mathrm{mg} \mathrm{kg}^{-1}$ & & & \\
\hline \multirow[t]{3}{*}{1} & $0-10$ & 426.3 & 1.8 & 154.7 & nd & nd & 394.1 & nd \\
\hline & $10-20$ & 87.4 & nd & 19.4 & nd & nd & 50.6 & nd \\
\hline & $20-40$ & 33.3 & nd & 12.0 & nd & nd & 10.2 & nd \\
\hline \multirow[t]{3}{*}{2} & $0-10$ & $3,988.8$ & 63.5 & $2,415.5$ & nd & 14.6 & $2,291.6$ & nd \\
\hline & $10-20$ & $2,995.4$ & 9.7 & $1,957.9$ & nd & 23.6 & $2,114.8$ & 1.9 \\
\hline & $20-40$ & $3,123.2$ & 7.7 & $1,968.8$ & nd & 19.4 & $2,404.9$ & 0.0 \\
\hline \multirow[t]{3}{*}{3} & $0-10$ & $15,293.1$ & 717.0 & $13,000.8$ & nd & nd & $6,091.9$ & 210.9 \\
\hline & $10-20$ & $17,913.2$ & 834.5 & $21,041.7$ & nd & nd & $6,989.6$ & 408.9 \\
\hline & $20-40$ & $19,434.0$ & 856.6 & $19,359.9$ & nd & nd & $5,999.9$ & 328.0 \\
\hline \multirow[t]{3}{*}{4} & $0-10$ & $3,892.7$ & 3.6 & $1,976.3$ & nd & nd & $1,647.4$ & nd \\
\hline & $10-20$ & $7,227.9$ & 3.1 & $2,208.3$ & 28.7 & 19.3 & $5,188.7$ & 142.7 \\
\hline & $20-40$ & $5,021.2$ & 3.4 & $2,275.0$ & 47.1 & 4.8 & $3,522.0$ & 15.3 \\
\hline \multirow[t]{3}{*}{5} & $0-10$ & $14,530.1$ & 3.0 & $8,514.8$ & 212.2 & nd & $7,017.0$ & $11,443.9$ \\
\hline & $10-20$ & $5,806.8$ & 3.1 & $4,102.7$ & nd & nd & $2,585.9$ & 88.0 \\
\hline & $20-40$ & $10,140.1$ & 3.7 & $8,937.4$ & nd & 3.1 & $4,272.0$ & 233.0 \\
\hline \multirow[t]{3}{*}{6} & $0-10$ & 695.9 & 175.0 & 283.5 & 44.0 & nd & 305.1 & nd \\
\hline & $10-20$ & 240.9 & 20.0 & 226.8 & nd & nd & nd & nd \\
\hline & $20-40$ & 105.4 & 2.8 & 128.7 & nd & nd & nd & nd \\
\hline \multirow[t]{3}{*}{7} & $0-10$ & $2,570.6$ & 14.7 & $1,919.8$ & nd & nd & $2,229.8$ & nd \\
\hline & $10-20$ & $1,266.7$ & 3.7 & 685.2 & nd & nd & $1,205.1$ & nd \\
\hline & $20-40$ & $1,270.6$ & 1.5 & 544.8 & nd & nd & $1,265.2$ & nd \\
\hline \multirow[t]{3}{*}{8} & $0-10$ & $4,796.3$ & 10.4 & $5,052.2$ & nd & nd & $1,638.7$ & 437.9 \\
\hline & $10-20$ & $6,062.1$ & 4.9 & $5,411.5$ & 18.2 & nd & $1,544.8$ & 725.4 \\
\hline & $20-40$ & $2,807.4$ & 1.8 & $2,512.7$ & nd & nd & $1,008.5$ & 189.7 \\
\hline
\end{tabular}

(1) Sequential extractions, with total dissolution of each phase after exchangeable $\left[\left(\mathrm{Ca}\left(\mathrm{NO}_{3}\right)_{2}\right]\right.$ treatment: carbonates (sodium acetate - $\mathrm{CH}_{3} \mathrm{COONa}$ ); organic matter (sodium hypochlorite - NaClO); amorphous and crystalline Fe oxides (Dithionite-CitrateBicarbonate - DCB); $\mathrm{Al}$ oxides, aluminosilicate of low crystallinity and kaolinite $(\mathrm{NaOH}+\mathrm{HCl})$; residual fractions $(\mathrm{HF} / \mathrm{HNO} /$ $\mathrm{H}_{2} \mathrm{O}_{2}$ ). nd: below the detection limit $\left(0.1 \mathrm{mg} \mathrm{kg}^{-1}\right)$ of the analytical method (ICP-AES).

Dilute acid solutions have been employed in kinetic studies for sequential dissolutions of Fe oxides: $\mathrm{pH}$ $1.5 \mathrm{HNO}_{3}$ (Bloom, 1983), $1 \mathrm{~mol} \mathrm{~L}-1$ HCl (Singh \& Gilkes, 1992). The acetic acid added to adjust the $\mathrm{pH}$ of sodium citrate solution (carbonate phase) may have solubilized less crystalline forms of the Fe oxides and promoted the extraction of $\mathrm{Pb}$ and $\mathrm{Zn}$ adsorbed specifically on the surface of hematite and goethite. Thus, according to this prior extraction, it is possible to associate the extracted $\mathrm{Zn}$ by dithionite-citratebicarbonate (DCB) (Table 4) to the structural forms: isomorphic substitutions of $\mathrm{Fe}$ by $\mathrm{Zn}$ in hematite and goethite (Lim-Nuñez \& Gilkes, 1987).

In soils with higher total $\mathrm{Zn}$ concentrations (3, 5 and 8), the levels of Zn-DCB ranged from 202.1 to $2,991.1 \mathrm{mg} \mathrm{kg}^{-1}$ (Table 4). The difference in ionic radius between $\mathrm{Fe}^{3+}(0.065 \mathrm{~nm})$ and $\mathrm{Zn}^{2+}(0.074 \mathrm{~nm})$, both in octahedral coordination, is only $14 \%$, less than $30 \%$, considered the upper limit for the occurrence of isomorphic substitution at low temperatures (Klein \& Hurlbut, 1993). The continuous contamination of soil with metallurgy residues and particulate forms emitted from the factory chimneys during the 50 years of activity (1945 to 1995) (Barros et al., 2010a) favored the inclusion of $\mathrm{Zn}^{2+}$ in the structure of $\mathrm{Fe}$ and $\mathrm{Mn}$ oxides by processes of occlusion and isomorphic substitution. The natural $\mathrm{Zn}$ levels in the soils of the area are low (reference sample 1). In magnetic $\mathrm{Fe}$ oxides, Batista et al. (2008) achieved high levels of $\mathrm{Fe}^{3+}$ for $\mathrm{Zn}^{2+}$ substitution in the structure of synthesized maghemites (maximum of $0.34 \mathrm{~mol} \mathrm{~mol}^{-1}$ ).

On the other hand, due to the larger ionic radius of $\mathrm{Pb}^{2+}(0.119 \mathrm{~nm})$ resulting in a greater difference to the radius of $\mathrm{Fe}^{3+}(83 \%)$, the occurrence of $\mathrm{Pb}$ in the octahedral structure of $\mathrm{Fe}$ oxides would be even more unlikely: $\mathrm{Pb}-\mathrm{DCB}$ contents and percentage of contributions of this phase in the total $\mathrm{Pb}$ were low (Table 3 and Figure 2, respectively). The $\mathrm{Pb}^{4+}$, with a more restricted occurrence (smaller ionic radius $0.078 \mathrm{~nm}-$ and a difference to the ionic radius of $\mathrm{Fe}^{3+}$ of only $20 \%$ ), was mentioned as substituent in the structure of goethite (Cornell \& Schwertmann, 1996). Similarly, other trace elements, e.g., $\mathrm{Ni}, \mathrm{Cr}, \mathrm{Co}, \mathrm{Cu}$, and $\mathrm{Ti}$, may be present in the structure of $\mathrm{Fe}$ oxides 
Table 4. Total $\mathrm{Zn}$ contents and different $\mathrm{Zn}$ forms obtained by sequential extractions from soil samples ${ }^{(1)}$

\begin{tabular}{|c|c|c|c|c|c|c|c|c|}
\hline Profile & Depth & Total & $\mathrm{Ca}\left(\mathrm{NO}_{3}\right)_{2}$ & $\mathrm{CH}_{3} \mathrm{COONa}$ & $\mathrm{NaClO}$ & DCB & $\mathrm{NaOH}$ & $\mathrm{HF} / \mathrm{HNO}_{3} / \mathrm{H}_{2} \mathrm{O}_{2}$ \\
\hline & $\mathrm{cm}$ & & & & $\mathrm{mg} \mathrm{kg}^{-1}$ & & & \\
\hline \multirow[t]{3}{*}{1} & $0-10$ & 70.0 & nd & 13.7 & nd & nd & 3.5 & 26.5 \\
\hline & $10-20$ & 16.6 & nd & nd & nd & nd & nd & 14.5 \\
\hline & $20-40$ & 8.8 & nd & nd & nd & nd & nd & 3.9 \\
\hline \multirow[t]{3}{*}{2} & $0-10$ & 135.6 & nd & 29.0 & nd & nd & nd & 32.9 \\
\hline & $10-20$ & 92.4 & nd & 9.0 & nd & nd & nd & 25.3 \\
\hline & $20-40$ & 83.2 & nd & 3.3 & nd & nd & nd & 20.8 \\
\hline \multirow[t]{3}{*}{3} & $0-10$ & $1,361.4$ & 181.4 & 654.8 & nd & 202.1 & 406.3 & 128.6 \\
\hline & $10-20$ & $1,618.6$ & 216.5 & 755.3 & nd & 219.4 & 454.0 & 201,0 \\
\hline & $20-40$ & $1,481.4$ & 231.5 & 657.2 & nd & 304.3 & 404.9 & 150.1 \\
\hline \multirow[t]{3}{*}{4} & $0-10$ & 142.7 & nd & 100.9 & nd & 1,1 & nd & 34.4 \\
\hline & $10-20$ & 45.8 & nd & 31.4 & nd & nd & nd & 2.7 \\
\hline & $20-40$ & 50.0 & nd & 57.2 & nd & nd & nd & 1.0 \\
\hline \multirow[t]{3}{*}{5} & $0-10$ & $19,719.7$ & 15.2 & 329.4 & 26.2 & $2,991.1$ & $12,727.2$ & $17,338.5$ \\
\hline & $10-20$ & $1,471.1$ & nd & 461.5 & nd & 271.5 & 437.4 & 319.4 \\
\hline & $20-40$ & $1,143.4$ & nd & 312.7 & nd & 230.5 & 623.5 & 412.5 \\
\hline \multirow[t]{3}{*}{6} & $0-10$ & 9.1 & nd & nd & nd & nd & nd & nd \\
\hline & $10-20$ & 12.0 & nd & nd & nd & nd & nd & nd \\
\hline & $20-40$ & 11.8 & nd & nd & nd & nd & nd & nd \\
\hline \multirow[t]{3}{*}{7} & $0-10$ & 234.6 & nd & 167.5 & nd & 31,8 & 4,4 & 63.4 \\
\hline & $10-20$ & 44.1 & nd & 27.2 & nd & nd & nd & 12.5 \\
\hline & $20-40$ & 60.3 & nd & 64.5 & nd & nd & nd & nd \\
\hline \multirow[t]{3}{*}{8} & $0-10$ & $3,778.2$ & 4.2 & 325.2 & nd & 764.5 & $3,284.7$ & $1,701.2$ \\
\hline & $10-20$ & $3,118.9$ & 0.3 & 290.1 & nd & 482.8 & $2,160.9$ & $2,041.1$ \\
\hline & $20-40$ & $1,926.0$ & nd & 301.8 & nd & 256.4 & 518.0 & 800.6 \\
\hline
\end{tabular}

(1) Sequential extractions, with total dissolution of each phase after exchangeable $\left[\left(\mathrm{Ca}\left(\mathrm{NO}_{3}\right)_{2}\right]\right.$ treatment: carbonates (sodium acetate $-\mathrm{CH}_{3} \mathrm{COONa}$ ); organic matter (sodium hypochlorite - $\mathrm{NaClO}$ ); amorphous and crystalline Fe oxides (Dithionite-CitrateBicarbonate - DCB); Al oxides, aluminosilicate of low crystallinity and kaolinite $(\mathrm{NaOH}+\mathrm{HCl}) ;$ residual $\left(\mathrm{HF}^{2} / \mathrm{HNO}_{3} / \mathrm{H}_{2} \mathrm{O}_{2}\right)$. nd: below the detection limit $\left(0.1 \mathrm{mg} \mathrm{kg}^{-1}\right)$ of the analytical method (ICP-AES).

(Singh \& Gilkes, 1992). In volcanic ash, Lu et al. (2009) found 1.6 times higher levels of trace elements (isomorphic substitution of $\mathrm{Fe}$ by $\mathrm{Mn}, \mathrm{Cr}, \mathrm{Cu}$, and $\mathrm{Cd}$ ) in the magnetic (mainly magnetite) than in the non-magnetic fractions.

The step of extracting metals specifically adsorbed in the structure of $\mathrm{Al}$ oxides (gibbsite), low crystalline aluminosilicate and kaolinite $\left(5 \mathrm{~mol} \mathrm{~L}^{-1} \mathrm{NaOH}\right)$ effectively reduced the residual fraction in total $\mathrm{Pb}$ contents (Figure 2). The average content of $\mathrm{Pb}$ in this mineral phase (extraction with $5 \mathrm{~mol} \mathrm{~L}^{-1} \mathrm{NaOH}$ at $220^{\circ} \mathrm{C}$ for $1.5 \mathrm{~h}$ ) was $2,712.2 \mathrm{mg} \mathrm{kg}^{-1}$, much higher than the average content extracted by Kummer et al. (2011) $\left(945.7 \mathrm{mg} \mathrm{kg}^{-1}\right)$ with a weaker extraction method $\left(1.5 \mathrm{~mol} \mathrm{~L}-1 \mathrm{NaOH}\right.$ at $75{ }^{\circ} \mathrm{C}$ for $1 \mathrm{~h}$ ). On the other hand, there was an inversion in $\mathrm{Pb}$ concentration and in the average participation in total levels of this metal in the residual phase compared to the data of Kummer et al. (2011) (592.7 vs. $2,062.5 \mathrm{mg} \mathrm{kg}^{-1}$ and $1.8 \mathrm{vs}$. $26.3 \%$, respectively), which is consistent with the greater extraction power (total contents at each step) of the method proposed here for sequential analysis. For $\mathrm{Zn}$, the average contribution of the residual fraction to the total metal content was 22.3 versus $50.1 \%$ reported by Kummer et al. (2011).

The importance of including the extraction with $5.0 \mathrm{~mol} \mathrm{~L}^{-1} \mathrm{NaOH}$ is clear, due to the large sample mass loss in this extraction (Table 5). Without this step, the residual fraction would be overestimated. The high sand content of soil 6 (Table 2), consisting mainly of quartz (Kummer et al., 2010), a mineral soluble in $\mathrm{HF}$, resulted in a high percentage of mass removal during the digestion of residual phase in sequential analysis (Table 5). In soil 5, due to the great occurrence of wastes from metallurgy on the surface and in the surface layer (Table 1), $24.4 \%$ of the total $\mathrm{Pb}$ was distributed in the residual fraction of the $0-10 \mathrm{~cm}$ layer (Figure 2), indicating low solubility of these wastes.

As gibbsite, low crystalline aluminosilicate and kaolinite minerals are dissolved with basic solutions (eg. $5 \mathrm{~mol} \mathrm{~L}^{-1} \mathrm{NaOH}$ ), these minerals were not affected by the $\mathrm{pH} 5.0$ sodium acetate solution, used in 


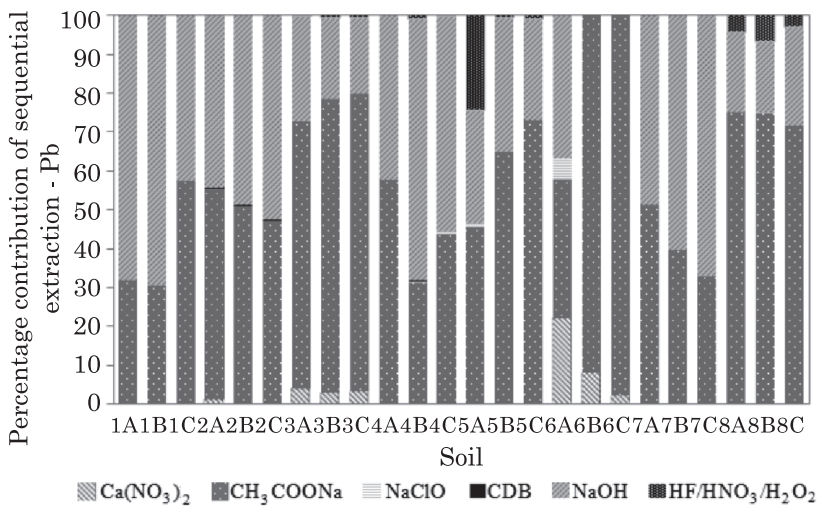

Figure 2. Percentage contribution of total $\mathbf{P b}$ concentrations in sequential extractions calculated considering the control of mass loss of the soil samples. Sequential extractions, with total dissolution of each phase after exchangeable $\left[\left(\mathrm{Ca}\left(\mathrm{NO}_{3}\right)_{2}\right]\right.$ treatment: carbonates (sodium acetate $-\mathrm{CH}_{3} \mathrm{COONa}$ ); organic matter (sodium hypochlorite - $\mathrm{NaClO}$ ); amorphous and crystalline Fe oxides (dithionite-citrate-bicarbonate - DCB); Al oxides, aluminosilicate of low crystallinity and kaolinite $(\mathrm{NaOH}+\mathrm{HCl})$; residual $\left(\mathrm{HF} / \mathrm{HNO}_{3} / \mathrm{H}_{2} \mathrm{O}_{2}\right)$. A: 0-10 cm, B: $10-20 \mathrm{~cm}$, C: $20-40 \mathrm{~cm}$. carbonate phase. Since there is a great difference between the ionic radius of $\mathrm{Al}^{3+}$ from the octahedral sheet of gibbsite and kaolinite and $\mathrm{Zn}^{2+}$ and $\mathrm{Pb}^{2+}(37$ and $203 \%$, respectively), a low isomorphic substitution of these elements is expected, especially for $\mathrm{Pb}$. Therefore, high $\mathrm{Pb}$ contents extracted with 5 mol L-1 $\mathrm{NaOH}$ were explained by a strong binding (inner sphere adsorption) of metal in the hydroxylated surface of these minerals, preventing $\mathrm{Pb}$ extraction in previous treatments. The mean $\mathrm{Pb}$ content in three depths of each soil extracted with $5 \mathrm{~mol} \mathrm{~L}^{-1} \mathrm{NaOH}$ was much higher than reported by Kummer et al. (2011) for the same step of sequential analysis (soil 1 - 7.5 times higher; soil 2 - 5.1; soil 3 - 5.0; soil 4 - 3.1; soil 5 - 2.6; soil 6 - 2.5; soil 7 - 5.2; soil 8 - 2.1). Since soil 1 (mean $\mathrm{Pb}$ concentration $151.6 \mathrm{mg} \mathrm{kg}^{-1}$ ) was sampled in a native vegetation area far away $(1.560 \mathrm{~m})$ from the factory (Table 1), the occlusion of $\mathrm{Pb}$ in the structure of the minerals extracted in this phase may be explained by natural processes. Site 1 was also considered by other authors as reference for the natural $\mathrm{Pb}$ concentrations of soils in the region of Adrianópolis (PR) (Andrade et al., 2009a.b; Barros et al., 2010a,b). The extraction with a more concentrated $\mathrm{NaOH}$ solution from soil 1 in relation to the method used by Kummer et al. (2011) resulted in the additional release of $\mathrm{Pb}$ forms more

Table 5. Percentage contribution of the sequential extractions in the mass loss of soil sample(1)

\begin{tabular}{|c|c|c|c|c|c|c|c|}
\hline Profile & Depth & $\mathrm{Ca}\left(\mathrm{NO}_{3}\right)_{2}$ & $\mathrm{CH}_{3} \mathrm{COONa}$ & $\mathrm{NaClO}$ & DCB & $\mathrm{NaOH}$ & $\mathrm{HF} / \mathrm{HNO}_{3} / \mathrm{H}_{2} \mathrm{O}_{2}$ \\
\hline & $\mathrm{cm}$ & & & 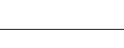 & 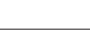 & & \\
\hline \multirow[t]{3}{*}{1} & $0-10$ & 0.0 & 4.4 & 8.4 & 5.6 & 34.9 & 46.7 \\
\hline & $10-20$ & 0.0 & 2.9 & 5.4 & 5.6 & 40.3 & 45.8 \\
\hline & $20-40$ & 0.0 & 2.8 & 5.3 & 5.7 & 38.3 & 48.0 \\
\hline \multirow[t]{3}{*}{2} & $0-10$ & 0.0 & 4,3 & 5.3 & 6.1 & 30.6 & 53.7 \\
\hline & $10-20$ & 0.0 & 3.9 & 4.7 & 4.8 & 31.7 & 54.9 \\
\hline & $20-40$ & 0.0 & 4.4 & 2.6 & 4.7 & 36.8 & 51.5 \\
\hline \multirow[t]{3}{*}{3} & $0-10$ & 0.0 & 5.5 & 6.7 & 6.9 & 44.6 & 36.3 \\
\hline & $10-20$ & 0.0 & 6.4 & 6.6 & 6.0 & 44.6 & 36.4 \\
\hline & $20-40$ & 0.0 & 5.6 & 5.4 & 7.2 & 45.2 & 36.7 \\
\hline \multirow[t]{3}{*}{4} & $0-10$ & 0.0 & 5.6 & 2.9 & 4.3 & 24.4 & 62.8 \\
\hline & $10-20$ & 0.0 & 3.3 & 1.2 & 6.7 & 43.6 & 45.2 \\
\hline & $20-40$ & 0.0 & 12.6 & 0.1 & 5.5 & 37.9 & 44.0 \\
\hline \multirow[t]{3}{*}{5} & $0-10$ & 0.0 & 27.7 & 1.6 & 6.8 & 37.5 & 26.5 \\
\hline & $10-20$ & 0.0 & 13.3 & 1.6 & 4.4 & 35.5 & 45.2 \\
\hline & $20-40$ & 0.0 & 23.1 & 1.6 & 5.5 & 32.2 & 37.6 \\
\hline \multirow[t]{3}{*}{6} & $0-10$ & 0.0 & 1.1 & 1.0 & 2.3 & 7.3 & 88.3 \\
\hline & $10-20$ & 0.0 & 0.6 & 0.5 & 1.9 & 5.8 & 91.2 \\
\hline & $20-40$ & 0.0 & 0.6 & 0.6 & 1.8 & 8.9 & 88.1 \\
\hline \multirow[t]{3}{*}{7} & $0-10$ & 0.0 & 6.8 & 3.5 & 8.5 & 41.8 & 39.4 \\
\hline & $10-20$ & 0.0 & 4.5 & 1.2 & 8.2 & 44.0 & 42.1 \\
\hline & $20-40$ & 0.0 & 3.7 & 1.6 & 8.0 & 45.0 & 41.8 \\
\hline \multirow[t]{3}{*}{8} & $0-10$ & 0.0 & 12.5 & 2.0 & 3.1 & 18.0 & 64.3 \\
\hline & $10-20$ & 0.0 & 11.3 & 1.4 & 3.4 & 20.1 & 63.8 \\
\hline & $20-40$ & 0.0 & 9.9 & 1.3 & 4.2 & 30.9 & 53.8 \\
\hline
\end{tabular}

(1) Sequential extractions, with total dissolution of each phase after exchangeable $\left[\left(\mathrm{Ca}\left(\mathrm{NO}_{3}\right)_{2}\right]\right.$ treatment: carbonates (sodium acetate $-\mathrm{CH}_{3} \mathrm{COONa}$ ); organic matter (sodium hypochlorite - $\mathrm{NaClO}$ ); amorphous and crystalline Fe oxides (Dithionite-CitrateBicarbonate - DCB); Al oxides, aluminosilicate of low crystallinity and kaolinite $(\mathrm{NaOH}+\mathrm{HCl}) ; \operatorname{residual}\left(\mathrm{HF} / \mathrm{HNO}_{3} / \mathrm{H}_{2} \mathrm{O}_{2}\right)$. 
tightly occluded in the minerals (7.5 times the amount extracted with $1.25 \mathrm{~mol} \mathrm{~L}^{-1} \mathrm{NaOH}$ or additional release of $395.1 \mathrm{mg} \mathrm{kg}^{-1}$, accumulated in the three layers of soil 1). In the other soil samples (2-8), this occlusion was intensified by significant soil $\mathrm{Pb}$ contamination in the area under anthropogenic influence (2.1 to 5.2 times higher than the mean concentration reported by Kummer et al., 2011).

With the prior and total extraction of $\mathrm{Fe}$ oxides with DCB (Mehra \& Jackson, 1960) and Al oxides, 1:1 aluminosilicates (Norrish \& Taylor, 1961) and part of the small-diameter and low-crystallinity $2: 1$ minerals (Melo et al., 2009) with $5 \mathrm{~mol} \mathrm{~L}^{-1} \mathrm{NaOH}$, the release of residual $\mathrm{Pb}$ and $\mathrm{Zn}$ forms $\left(\mathrm{HF} / \mathrm{HNO}_{3} / \mathrm{H}_{2} \mathrm{O}_{2}\right.$ extraction - Tables 3 and 4 ) was related to the presence of high crystalline $2: 1$ and tectosilicate minerals and refractory oxides (Melo et al., 2002).

The predominance of quartz and occurrence of other primary minerals in silt and sand fractions interfered with the identification of clay minerals in the soil samples (Figure 3). However, it was observed that as some secondary minerals were eliminated in the steps of sequential extractions, the diffractograms were "cleaned" and the peaks of lower intensity quartz were becoming more evident. The most intense and narrow peaks are characteristic of primary minerals with a high crystallinity degree in the sand and silt fractions (Melo et al., 2002).

The typical reflection of calcite/dolomite from 29.4 to $30.9^{\circ} 2 \theta$ (CuKa radiation) disappeared with $\mathrm{pH} 5.0$ sodium acetate extraction (Figure 3a,b), demonstrating the effectiveness of treatment to determine $\mathrm{Pb}$ and $\mathrm{Zn}$ associated with carbonates. After DCB extraction, the removal of Fe oxides was not observed, since these minerals were not identified in the soil sample without treatment due to the high levels of primary minerals, mainly quartz (Figure 3c). Even in the clay fraction, hematite and goethite concentrations were low (Table 2). The predominance of kaolinite in the clay fraction (around $500 \mathrm{~g} \mathrm{~kg}^{-1}$ Table 2) was insufficient for the correct identification of mineral reflections by XRD in soil. However, the

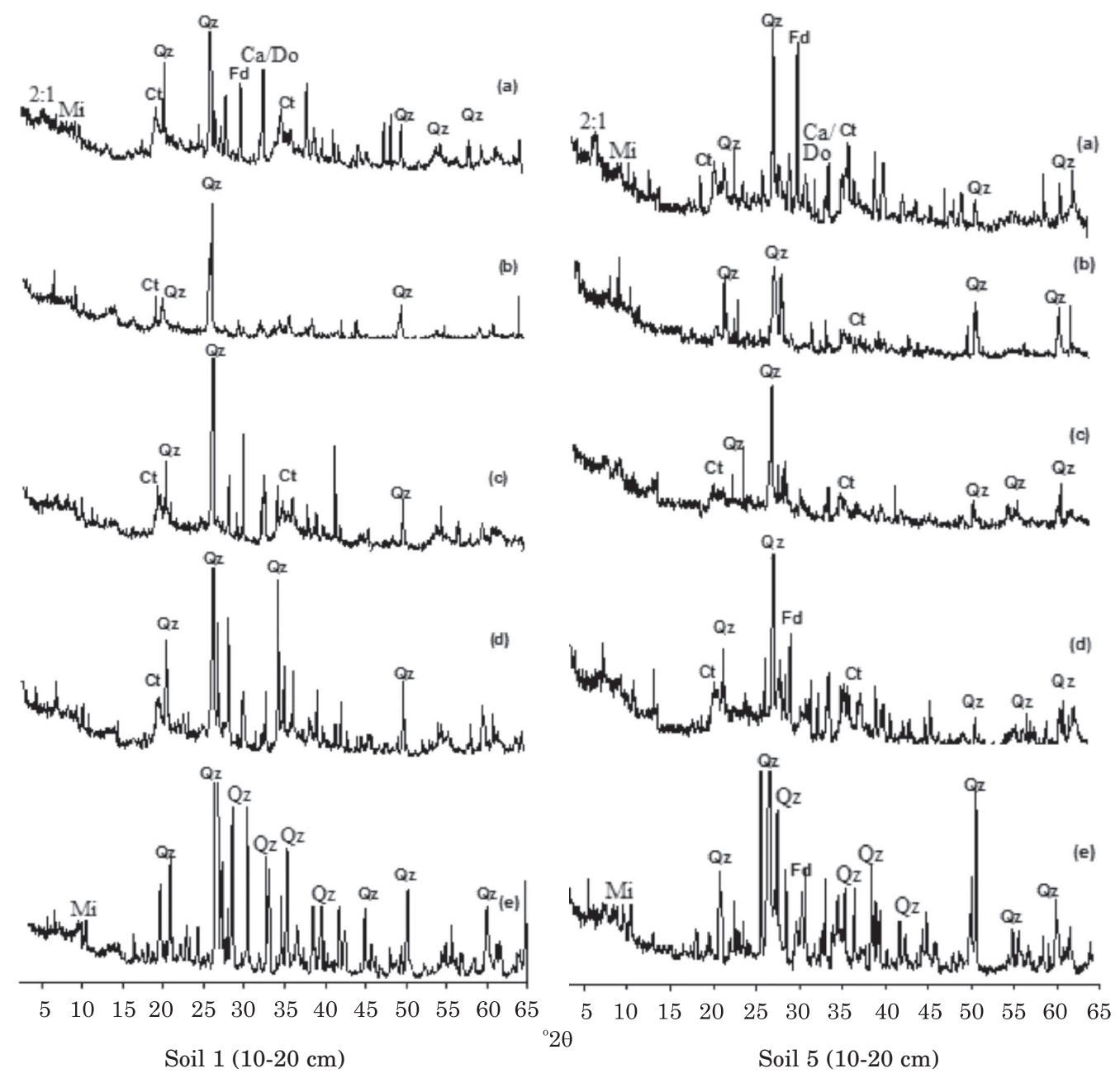

Figure 3. X-ray diffraction of two soil samples showing the mineralogy evolution with the sequential treatments: (a) without treatment, (b) after $\mathrm{CH}_{3} \mathrm{COONa}$, (c) after $\mathrm{NaClO}$, (d) after DCB, (e) after $\mathrm{NaOH}$. Ct: kaolinite, Fd: feldspar, Qz: quartz, Mi: mica, 2:1 - 2:1 secondary mineral, Ca/Do: calcite/dolomite. 
diffractogram produced after the step with $5 \mathrm{~mol} \mathrm{~L}^{-1}$ $\mathrm{NaOH}$ showed a total removal of this mineral (Figure $3)$. Melo et al. $(2002,2003)$ used a similar method of sequential extraction for speciation of total $\mathrm{K}$ in the clay fraction of soils from different regions of Brazil and confirmed the complete removal of mineral phases at each step by X-ray diffraction.

In addition to the difficulties of monitoring the mineral removal with the use of soil samples in sequential analyses (Figure 3), the great amount of quartz in the sand and silt prevented the accurate identification of the peaks positions in the XRD patterns of secondary minerals. Some authors used the shift from the standard position of these peaks (change in the d-spacing), which reflect lattice parameters of the framework, to estimate the level of isomorphic substitution of heavy metals in the structure of secondary soil minerals (Castaldi et al., 2008; Eren \& Afisin, 2008). For example, due to differences in the ionic radius, the increase in $\mathrm{Fe}^{3+}$ for $\mathrm{Zn}^{2+}$ substitution, [ $\mathrm{Zn} \mathrm{mol} \mathrm{mol}{ }^{-1}$ ] increased the dimension $\mathrm{a}_{0}$ of the cubic unit cells of the maghemites according to the regression equation: $\mathrm{a}_{0}=0.8343+$ $0.02591 \mathrm{Zn}\left(\mathrm{R}^{2}=0.98\right)$ (Batista et al., 2008).

As expected, the larger diameter and crystalline 2:1 minerals, quartz, mica, feldspar were not attacked by sequential procedures of selective dissolution (Jackson et al., 1986; Melo et al., 2002, 2003), being concentrated in the residual fraction (Figure 3e).

\section{CONCLUSIONS}

1. The sequential extraction method was efficient for the total removal of each mineral phase and for the complete release of occluded and structural forms of $\mathrm{Pb}$ and $\mathrm{Zn}$. There was lower association of these metals with primary and 2:1 minerals and refractory oxides (residual phase).

2. For soils without limestone as parent material, the exclusion of extraction with $\mathrm{pH} 5.0$ sodium acetate is recommended in the sequential analysis. For alkaline soils the development of a new, more selective method is required to determine heavy metal contents in the carbonate phase.

3. The higher incidence of $\mathrm{Zn}$ than $\mathrm{Pb}$ in the structure of $\mathrm{Fe}$ oxides, due to isomorphic substitution, was attributed to a smaller difference between ionic radius of $\mathrm{Zn}^{2+}$ and $\mathrm{Fe}^{3+}$. The predominance of kaolinite in the clay fraction was responsible for the high release of $\mathrm{Pb}$.

4. Monitoring the removal and d-spacing (the isomorphic substitution among metals causes some changes in the lattice parameters of the framework) of clay minerals with sequential treatments by X-ray diffraction was not efficient in the studied soil samples due to high occurrence of quartz and other primary minerals in coarser fractions.

\section{LITERATURE CITED}

AUERNHEIMER, C. \& CHINCHON, S. Calcareous skeletons of sea urchins as indicators of heavy metals pollution. Portman Bay, Spain. Environ. Geol., 29:78-83, 1997.

ANDRADE, M.G.; MELO, V.F.; GABARDO, J.; SOUZA, L.C.P. \& REISSMANN, C.B. Metais pesados em solos de área de mineração e metalurgia de chumbo: I - Fitoextração. R. Bras. Ci. Solo, 33:1879-1888, 2009a.

ANDRADE, M.G.; MELO, V.F..; GABARDO, J.; SOUZA, L.C. P. \& REISSMANN, C.B. Metais pesados em solos de área de mineração e metalurgia de chumbo. II - Formas e disponibilidade para plantas. R. Bras. Ci. Solo, 33:18891897, 2009b.

BARROS, Y.J.; MELO, V.F.; DIONÍSIO, J.A.; CARON, L.; OLIVEIRA, E.B.; AZEVEDO, J.C.R. \& SOUZA, L.C.P. Indicadores de qualidade de solos de área de mineração e metalurgia de chumbo: I- Microbiologia. R. Bras. Ci. Solo, 34:1397-1411, 2010a.

BARROS, Y.J.; MELO, V.F.; SAUTTER, K.D.; BUSCHLE, B.; OLIVEIRA, E.B.; AZEVEDO, J.C.R. \& SOUZA, L.C.P. Indicadores de qualidade de solos de área de mineração e metalurgia de chumbo: II - Mesofauna e plantas. R. Bras. Ci. Solo, 34:1413-1426, 2010b.

BATISTA, M.A.; COSTA, A.C.S.; SOUZA JUNIOR, I.G. \& BIGHAM, J.M. Crystallochemical characterization of synthetic $\mathrm{Zn}$-substituted maghemites $\left(\mathrm{g}-\mathrm{Fe}_{2-\mathrm{x}} \mathrm{Zn}_{\mathrm{x}} \mathrm{O}_{3}\right)$. R. Bras. Ci. Solo, 32:561-568, 2008.

BLOOM, P.R. The kinetics of gibbsite dissolution in nitric acid. Soil Sci. Soc. Am. J., 47:164-168, 1983.

BUSCHELE, B.N.; PALMEIRO, J.K.; YOUSSEF BACILA SADE, Y.B.; MELO, V.F.; ANDRADE, M.G \& BATISTA, A.H. Cinética de liberação de chumbo de solos de área de mineração e metalurgia de metais pesados. R. Bras. Ci. Solo, 34:1865-1874, 2010.

CASTALDI, P.; SANTONA, L.; ENZO, S. \& MELIS, P. Sorption processes and XRD analysis of a natural zeolite exchanged with $\mathrm{Pb}^{2+}, \mathrm{Cd}^{2+}$ and $\mathrm{Zn}^{2+}$ cations. J. Hazard. Mat., 156:428434, 2008.

CORNELL, R.M. \& SCHWERTMANN, U. The iron oxides. Weinheim, VCH Publ., 1996. 573p.

EMPRESA BRASILEIRA DE PESQUISA AGROPECUÁRIA EMBRAPA. Manual de métodos de análise de solo. 2.ed. Rio de Janeiro, 1997. 212p.

EREN, E. \& AFSIN, B. An investigation of $\mathrm{Cu}(\mathrm{II})$ adsorption by raw and acid-activated bentonite: A combined potentiometric, thermodynamic, XRD, IR, DTA study. J. Hazard. Mat., 151:682-691, 2008.

JACKSON, M.L.; LIM, C.H. \& ZELAZNY, L.W. Oxides, hydroxides, and aluminosilicates. In: KLUTE, A., ed. Methods of soil analysis; Physical and mineralogical methods. Madison, American Society of Agronomy, 1986. Parte 1: p.101-150.

KABATA PENDIAS, A. \& PENDIAS, H. Trace elements in soils and plants. Boca Ratón, CCR, 2001. 413p. 
KLEIN, C. \& HURLBUT, C.S. Manual of mineralogy. 21.ed. New York, John Wiley \& Sons, 1993. 681p.

KUMMER, L.; MELO, V.F.; BARROS, Y. \& AZEVEDO, J.C. Uso da análise de componentes principais para agrupamento de amostras de solos com base na granulometria e em características químicas e mineralógicas. Sci. Agríc., 11:469-480, 2010.

KUMMER. L.; MELO, V.F.; BARROS, Y.J. \& AZEVEDO, J.C.R. Extrações sequenciais de chumbo e zinco em solos de área de mineração e metalurgia de metais pesados. $R$. Bras. Ci. Solo, 35:2005-2018, 2011.

LIANG, X.; HOU, W.; XU, Y.; SUN, G.; WANG, L.; SUN, Y. \& QIN, X. Sorption of lead ion by layered double hydroxide intercalated with diethylenetriaminepentaacetic acid. Colloids Surf. A: Physicochem. Eng. Aspects, 366:50-57, 2010.

LIM-NUÑEZ, R. \& GILKES, R.J. Acid dissolution of metalcontaining goethites and haematites. Inter. J. Miner. Proc., 80:144-152, 1987.

LINDSAY, W.L. Chemical equilibria in soils. New Jersey, Blackburn, 2001.449p.

LU, S.G.; CHEN, Y.Y.; SHAN, W.D. \& BAI, S.Q. Mineralogy and heavy metal leachability of magnetic fractions separated from some Chinese coal fly ashes. J. Hazard. Mat., 169:246-255, 2009.

LUCKHAM, P.F. \& ROSSI, S. The colloidal and rheological properties of bentonite suspensions. Adv. Colloid Interface Sci., 82:43-92, 1999.

MANN, S.S. \& RITCHIE, G.S.P. The influence of $\mathrm{pH}$ on the forms of cadmium in four west Australian soils. Austr. J. Soil Res., 31:255-270, 1993.

MEHRA, O.P. \& JACKSON, M.L. Iron oxide removal from soils and clay by a dithionite-citrate system buffered with sodium bicarbonate. Clays Clay Miner., 7:317-327, 1960.

MELO, V.F.; SINGH, B.; SCHAEFER, C.E.G.R.; NOVAIS, R.F. \& FONTES, M.P.F. Chemical and mineralogical properties of kaolinite-rich Brazilian soils. Soil Sci. Soc. Am. J., 65:1324-1333, 2001.

MELO, V.F.; SCHAEFER, C.E.G.R.; NOVAIS, R.F.; SINGH, B. \& FONTES, M.P.F. Potassium and magnesium in clay minerals of some Brazilian soil as indicated by a sequential extraction procedure. Commun. Soil Sci. Plant Anal., 33:2203-2225, 2002.

MELO, V.F.; CORRÊA, G.F.; MASCHIO, P.A.; RIBEIRO, A.N. \& LIMA, V.C. Importância das espécies minerais no potássio total da fração argila de solos do Triângulo Mineiro. R. Bras. Ci. Solo, 27:807-819, 2003.

MELO, V.F.; MATTOS, J.M. \& LIMA, V.C. Métodos de concentração de amostras da fração argila e de identificação de minerais 2:1. R. Bras. Ci. Solo, 33:527$539,2009$.

MELO, V.F.; ANDRADE, M.; GRASSI, M.T.; CAMPOS, M.S.; BATISTA, A.H. \& AVARETTO, N. Chumbo e zinco em águas e sedimentos de área de mineração e metalurgia de metais. Quím. Nova, 35:22-29, 2012
MILLER, W.P.; MARTENS, D.C. \& ZELAZNY, L.W. Effect of sequence in extraction of trace metals from soils. Soil Sci. Soc. Am. J., 50:598-601, 1986.

NORRISH, K. \& TAYLOR, M. The isomorphous replacement of iron by aluminium in soil goethites. J. Soil Sci., 12:294306, 1961.

PERIN, G.; FABRIS, R; MANENTE, S.; WAGENER, A.R.; HAMACHER, C. \& SCOTTO, S. A five-year study on the heavy-metal pollution of Guanabara Bay sediments (Rio de Janeiro, Brazil) and evaluation of the metal bioavailability by means of geochemical speciation. Water Res., 31:3017-3028, 1997.

RAKSASATAYA, M.; LANGDOM, A.G. \& KIM, N.D. Assessment of the extent of lead redistribution during sequential extraction by two different methods. Anal. Chim. Acta, 332:1-14, 1996.

SHIOWATANA, J.; TANTIDANAI, N.; NOOKABKAEW, S. \& NACAPRICHA, D.A. Novel continuous-flow sequential extraction procedure for metal speciation in solids. J. Environ. Qual., 30:1195-1205, 2001.

SHUMAN, L.M. Zinc, manganese and copper in soil fractions. Soil Sci., 127:10-17, 1979.

SCHWERTMANN, U. \& FECHTER, H. The influence of aluminium on iron oxides. XI. Aluminium substituted maghemite in soils and its formation. Soil Sci. Soc. Am. J., 48:1462-1463, 1984.

SINGH, B. \& GILKES, R.J. Concentration of iron oxides from soil clays by $5 \mathrm{M} \mathrm{NaOH}$ treatment: The complete removal of sodalite and kaolin. Clay Miner., 26:463-472, 1991.

SINGH, B. \& GILKES, R.J. Properties and distribution of iron oxides and their association with minor elements in the soil of south-western Australia. J. Soil Sci., 43:77-98, 1992.

SPOSITO, G.; LUND, L.J. \& CHANG, A.C. Trace metal chemistry in arid-zonefield soils amended with sewage sludge: I. Fractionation of $\mathrm{Ni}, \mathrm{Cu}, \mathrm{Zn}, \mathrm{Cd}$, and $\mathrm{Pb}$ in solid phases. Soil Sci. Soc. Am. J., 46:260-264, 1982.

STOVER, R.C.; SOMMERS, L.E. \& SILVIEIRA, D.J. Evaluation of metals in waste-water sludge. J. Water Pollut. Control Feder., 48:2165-2175, 1976.

TESSIER, A.; CAMPBELL, P.G.C. \& BISSON, M. Sequential extraction procedure for the speciation of particulate trace metals. Anal. Chem., 51:844-851, 1979.

TU, Q.; SHAN, X.Q.; QIAN, J. \& NI, Z.M. Trace metal redistribution during extraction of model soils by acetic acid/sodium acetate. Anal. Chem., 66:3562-3598, 1994.

UNITED STATES ENVIRONMENTAL PROTECTION AGENCY - USEPA. Method 5052 - Microwave assisted acid digestion of siliceous and organically based matrices. Washington, DC, 1996.

VALENTE, J.S.; HERNANDEZ-CORTEZ, J.; CANTU, M.S.; FERRAT, G. \& PEZ-SALINAS, E.L. Calcined layered double hydroxides $\mathrm{Mg}-\mathrm{Me}-\mathrm{Al}(\mathrm{Me}: \mathrm{Cu}, \mathrm{Fe}, \mathrm{Ni}, \mathrm{Zn}$ ) as bifunctional catalysts. Catalysis Today, 150:340-345, 2010.

ZHANG, M.; LI, W.; YANG, Y.; CHEN, B. \& SONG, F. Effects of readily dispersible colloid on adsorption and transport of $\mathrm{Zn}, \mathrm{Cu}$, and $\mathrm{Pb}$ in soils. Environ. Intern., 31:840-844, 2005. 